\title{
Treatment of Multiple Sclerosis
}

\author{
M. Nadeem1 ${ }^{1}$, O. Mufti², I. Ahsan ${ }^{3}$, R. Naheed ${ }^{4}$, S. M. Faheem ${ }^{5}$ \\ ${ }^{1}$ Muhammad Nadeem MBBS, SUNY, Buffalo, NY, USA \\ ${ }^{2}$ Owais Mufti MD, SUNY, Buffalo, NY, USA \\ ${ }^{3}$ Irfan Ahsan MD, Abington Memorial Hospital, Abington, PA, USA \\ ${ }^{4}$ Rabia Naheed MBBS, Fatima Memorial Hospital, Lahore, Pakistan \\ ${ }^{5}$ Sheikh Muhammad Faheem MBBS, University of IOWA Hospital, lowa City, IA, USA \\ Email: drnadeem168@gmail.com, muftiowais2001@rediffmail.com, irfanahsan@kemu.edu.pk, \\ drrnaheed@gmail.com,drfaheem@kemu.edu.pk
}

Received 16 September 2014; accepted 19 June 2016; published 22 June 2016

Copyright (C) 2016 by authors and Scientific Research Publishing Inc.

This work is licensed under the Creative Commons Attribution International License (CC BY).

http://creativecommons.org/licenses/by/4.0/

c) (i) Open Access

\begin{abstract}
Background: A new method of immune-based therapies has been made and applied on multiple sclerosis patients in last decades. Some of these treatments have a high efficacy and reasonable side effects. In slowing disease progression, present treatments have significant limitations, but often associated with significant adverse effects of immunosuppression, with having a bit low capability to counter the disability. Methods: This is a review meta-analysis of treatment of multiple sclerosis. Results: Thus a valuable aim for multiple sclerosis clinical research is to introduce more effective therapies. Conclusion: It is absolutely necessary to increase the individualized therapy planes development in respect to make better planes to disease-modifying treatments.
\end{abstract}

\section{Keywords}

Immune Sequestration, Multiple Sclerosis, Non-Specific Immune Modulation, Lymphocyte-Targeted Therapy

\section{Introduction}

Current progress of the immunopathogenesis of multiple sclerosis (MS) has made the development of promising and novel neurotherapeutic strategies. This review meta-analysis study summarizes Phase II and phase III clinical trials updated data explaining the clinical safety and efficacy promising therapeutic interventions in MS patients $(\mathrm{Pt})$. But adverse effects may get to our knowledge with more Pt studies and increase use of the drugs (Table 1). 
Table 1. Selected MS therapies.

\begin{tabular}{|c|c|c|c|c|c|}
\hline $\begin{array}{c}\text { Lymphocyte-targeted } \\
\text { therapy }\end{array}$ & Mechanism of action & Route/Dose & Results & Status & AEDs \\
\hline Alemtuzumab & Anti-CD52 & IV $12 \mathrm{mg}$ dose $/ \mathrm{y}$ & $\begin{array}{l}75 \% \downarrow \text { SAD }(12 \mathrm{mg} \\
\text { dose }), 74 \% \downarrow \text { RR }\end{array}$ & Phase III & $\begin{array}{l}\text { ITP ( } 3 \text { pts }) \text {, Graves disease } \\
(20 \%)\end{array}$ \\
\hline Rituximab & Anti-CD20 & $\begin{array}{l}\text { IV ( } 1 \text { gram dose, } Q 2 \mathrm{w}, \\
\times 2)\end{array}$ & $\begin{array}{l}91 \% \downarrow \text { CEL in } \\
\text { RRMS }\end{array}$ & Phase II & Infusion reaction, allergies \\
\hline Cladribine & $\begin{array}{l}\text { Purine nucleoside } \\
\text { analog }\end{array}$ & $\begin{array}{l}\text { Oral ( } 3.5 \text { and } 5.25 \\
\mathrm{mg} / \mathrm{kg} \text { total dose })\end{array}$ & $\begin{array}{l}58 \% \downarrow R R, 43 \% \\
\text { disease free }\end{array}$ & Phase III & $\begin{array}{l}\text { HZV, lymphopenia, HA, } \\
\text { nasopharyngitis, } \\
\text { lymphopenia }\end{array}$ \\
\hline Daclizumab & Anti-CD25/anti-IL2 & SQ 2 mg/kg (Q2w) & $\begin{array}{l}72 \% \downarrow \mathrm{CEL} \text { in } \\
\text { RRMS patients }\end{array}$ & Phase II & $\begin{array}{l}\text { Skin rash, chest } \\
\text { discomfort, headaches, } \\
\text { lymphopenia }\end{array}$ \\
\hline CTLA4Ig & $\begin{array}{l}\text { Prevents T cell } \\
\text { activation }\end{array}$ & $\begin{array}{l}\text { IV }(2,10.0,20.0 \text {, or } \\
35.0 \mathrm{mg} / \mathrm{kg})\end{array}$ & $\begin{array}{l}\text { No significant } \\
\text { changes }\end{array}$ & Phase I & $\begin{array}{l}\text { Lymphadenopathy, } \\
\text { urinary tract infections, } \\
\text { headaches, blurred vision, } \\
\text { and upper respiratory tract } \\
\text { infections }\end{array}$ \\
\hline \multicolumn{6}{|l|}{ Immune sequestration } \\
\hline Fingolimod & $\begin{array}{l}\text { Sphingosine-1- } \\
\text { phosphate (S1P) analog }\end{array}$ & Oral (1.25 and $5 \mathrm{mg})$ & $\begin{array}{l}80 \% \downarrow \text { CEL, } 50 \% \downarrow \\
\mathrm{RR}\end{array}$ & Phase III & $\begin{array}{l}\text { Bradycardia, } \\
\text { nasopharyngitis, dyspnea, } \\
\text { headaches, diarrhea, } \\
\text { nausea, encephalitis, skin } \\
\text { cancer }\end{array}$ \\
\hline SB-683699 & $\begin{array}{l}\text { Alpha-4 integrin } \\
\text { antagonist }\end{array}$ & $\begin{array}{l}\text { Oral (150 - } 1200 \mathrm{mg} \\
\text { Twice Daily) }\end{array}$ & No data available & Phase II & No data available \\
\hline \multicolumn{6}{|c|}{ Unspecific immune suppression } \\
\hline Laquinimod & Antiinflammatory & Oral $0.6 \mathrm{mg} / \mathrm{d}$ & $40 \% \downarrow \mathrm{CEL}$ & Phase III & $\begin{array}{l}\text { LFT elevation, Budd } \\
\text { Chiari }\end{array}$ \\
\hline Fumaric acid (BG12) & $\begin{array}{l}\text { Antiinflammatory/ } \\
\text { Neuroprotective }\end{array}$ & $\begin{array}{l}\text { Oral }(120-240 \mathrm{mg} \\
\text { TID) }\end{array}$ & $69 \% \downarrow \mathrm{CEL}$ & Phase III & $\begin{array}{l}\text { Diarrhea, cramps, nausea } \\
\text { and flushing }\end{array}$ \\
\hline Teriflunomide & $\begin{array}{l}\text { Inhibition of immune } \\
\text { cell proliferation }\end{array}$ & Oral ( 7 and $14 \mathrm{mg}$ dose) & $61 \% \downarrow \mathrm{CEL}$ & Phase II & $\begin{array}{l}\text { Nasopharyngitis, alopecia, } \\
\text { nausea, limb pain, } \\
\text { diarrhea, and arthralgia }\end{array}$ \\
\hline
\end{tabular}

\section{Lymphocyte-Targeted Therapy}

\subsection{Cladribine}

It is a purine nucleoside analogue with lymphotoxic effects when combined into the deoxyribonucleotide acid (DNA) of dividing and resting cells having increased deoxycytidine kinase activity (lymphocytes and monocytes), and subsequent stoping of DNA replication, DNA damage, and cell death [1]. In computing to its lymphotoxic effects, by inhibiting S-adenosyl homocysteine hydrolase and DNA methylation, it possesses epigenetic properties [2]. In the 1980s, FDA approved it for treatment of hairy cell leukemia.

It parenterally (total dose $2.8 \mathrm{mg} / \mathrm{kg}$ ) significantly decreased the volume and number of $\mathrm{T}_{1}$ gadolinium- enhancing lesions, accumulation of $\mathrm{T}_{2}$ lesion volume, disability progression and relapse rate in $\mathrm{Pt}$ with progressive and relapsing forms of MS [3]-[5]. Because of dose-dependent increase in side effects was observed, as oral tablet formulation, we are going to selection of low doses for use in an ongoing clinical development program.

Using it orally in Pt with relapsing-remitting MS (RRMS), a recent placebo-controlled Phase III trial, showed a $58 \%$ reduction in annualized relapse rates $(3.5 \mathrm{mg} / \mathrm{kg}$ daily for 4 to 5 days, with two courses in the first year) at two years compared with placebo [44]. In addition, compared with $61 \%$ of $\mathrm{Pt}$ in the placebo group, $80 \%$ of Pt remained relapse-free ( $\mathrm{P}<0.001$ for both dose regimens). Relative to $\mathrm{Pt}$ in the control group, $\mathrm{Pt}$ in the active drug group experienced a $30 \%$ reduction in the risk of disability progression [6]. Side effects included headaches, nausea, upper respiratory tract infections, and nasopharyngitis. Lymphopenia occurred more frequently in the active drug group (22\%). Pt treated with it, $2.3 \%$ reported herpes zoster virus (HZV) infections, although these were localized to the skin and were responsive to preventative treatment. For Pt with relapsing MS, it has 
the potential to be the first orally administered disease-modifying therapy available [44].

\subsection{Alemtuzumab}

It is a humanized monoclonal antibody (Ab) directed against CD52, a cell surface receptor expressed on monocytes, natural killer cells, lymphocytes, and macrophages. It binds to T- and B- lymphocytes, resulting in $\mathrm{Ab}$-dependent cell lysis, and subsequent elimination from the blood and bone marrow, with the effect lasting up to 16 months. As a matter of interest, immune cells (IC) regeneration capacity remains intact after repetitive drug therapies, in the course of immune reconstitution, premature forms of B-cells (transitional type I cells) possibly activated by high B-cell activation factor levels are seen early. This event could bring into light the development and association of Ab-mediated autoimmune disorders seen in the course of its treatment. It is currently FDA-approved to treat B-cell chronic lymphocytic leukemia (CLL).

Its studies in the treatment of Pt with secondary progressive MS (SPMS) relapsing-remitting (RR) have suggested efficacy in the suppression of annualized relapse rates, but depending on stages of the disease, with variable results in preventing progression of disability. Its intravenous (IV) recent Phase II randomized blinded clinical trial at 12 or $24 \mathrm{mg}$ per day for five consecutive days during the first month and on three consecutive days at 12 and 24 months, compared with IFN $\beta$-1a in Pt with early RRMS, it decreased the rate of sustained accumulation of disability by $71 \%$, with a $74 \%$ reduction in the annualized rate of relapse significantly. About $80 \%$ of Pt receiving it remained relapse-free at 36 months [44]. Decrease in total brain volume and $\mathrm{T}_{2}$ lesion volume analysis was greater in the Pt receiving it. Side effects in the Pt receiving it included thrombocytopenic purpura, autoimmune thyroid disorders and infections. About one-third of Pt develops Ab against the thyrotropin receptor and subsequently develops autoimmune hyperthyroidism [7].

\subsection{Rituximab}

It is a chimeric Ab directed against human CD20 phosphoprotein present on all B-cell lineages except for plasma cells, stem cells and pro-B cells. It acts by binding to B-cell lymphocytes, initiating a series of events that leads to B-cell lysis and subsequent depletion. The benefit of decrease of B-cell in controlling the course of the disease supports the recently recognized active role of B-cells in the pathogenesis of MS. The standard dose of it is $375 \mathrm{mg} / \mathrm{m}^{2}$ given weekly for four weeks, or a fixed dose of $2 \mathrm{~g}$ divided into two infusions of $1 \mathrm{~g}$ each two weeks apart. Following $2 \mathrm{~g}$ of it IV administration, CD20 positive B-cells are rapidly decreased and remain undetectable for up to six months longer.

It has shown efficacy in the treatment of Pt with RRMS. A 91\% decrease in the number of gadolinium- enhancing lesions on (magnetic resonance imaging (MRI) scans, as well as a significant decrease in the number of clinical relapses is demonstrated by a recently completed randomized clinical trial using a standard dose of it in RRMS Pt. Mild infusion-related side effects were seen in most Pt, but serious side effects were rare [8]. In a recent trial of Pt with primary progressive multiple sclerosis (PPMS), it appeared to have efficacy only in young Pt with signs of active inflammation on MRI scans [9]. Five cases of progressive multifocal leukoencephalopathy [45] (PML) have been recently reported in Pt receiving it for the treatment of rheumatoid arthritis (RA) and systemic lupus erythematosus. However, these Pt were receiving other immunosuppresants [44].

Ocrelizumab, a humanized monoclonal Ab against human CD20, is currently under investigation in a Phase II trial evaluating its safety and efficacy in Pt with RRMS [10]. Given the functional similarities between it and rituximab, it is unclear which of these will be developed for use in MS [44].

\subsection{Daclizumab}

It is a humanized mouse monoclonal $\mathrm{Ab}$ that binds to the alpha-subunit of the interleukin (IL)-2 receptor. This receptor is present on activated B- and T-cells but not on natural killer (NK) cells, and is important for T-cell activation and proliferation. The clinical benefit of it has been linked to significant expansion of immunoregulatory CD56 NK cells, and subsequent down regulation of adaptive T-cell responses (CD8 and CD4 positive T-cells) [11]. Compared with baseline, in an initial open-label study with IV of it $1 \mathrm{mg} / \mathrm{kg}$, five Pt with SPMS and six Pt with RRMS demonstrated a reduction in number of contrast-enhancing lesions by $78 \%$ and in relapse rate by $81 \%$ [12]. Compared with Pt receiving IFN $\beta$ alone, a recent open-label Phase II trial using subcutaneous (SQ) of it $2 \mathrm{mg} / \mathrm{kg}$ in MS Pt with inadequate response to IFN $\beta$ therapy, demonstrated a $72 \%$ reduction in the 
number of new or enlarged contrast-enhancing lesions at week 24. Because Type I IFN is also known to enhance NK cell function, the question of possible synergism between IFN and it treatment is raised [13] [44]. Chest discomfort, generalized lymphadenopathy, lymphopenia, headaches, Skin rash, and transient elevation of bilirubin levels and liver function tests have been reported. It is already in clinical use to prevent rejection of kidney transplants. A multicenter Phase II trial investigating a SC formulation of its monotherapy is ongoing.

\subsection{CTLA-4 Ig}

It is a chimeric fusion protein that inhibits T-cell activation by binding the B7-1 and B7-2 costimulatory molecules on antigen-presenting cells. A recent Phase I clinical trial showed that IV administration of it was well tolerated in Pt with MS, and most side effects were rated as mild. Headaches, lymphadenopathy, upper respiratory tract infections, urinary tract infections and blurred vision were most frequently reported. Immunologic assessment of the Pt showed a decrease in myelin basic protein proliferation within two months of infusion and reduced IFN- $\gamma$ production by myelin basic protein-specific lines. During the study no significant changes in clinical or MRI parameters were observed [14].

\section{Immune Sequestration}

\subsection{Fingolimod (FTY720)}

It, an oral sphingosine-1-phosphate (S1P) analog, acts as a partial agonist on S1P receptors, inducing internalization of the S1P receptor, thereby inhibiting the mechanism necessary for lymphocytes to migrate out of secondary lymphoid structures. It is associated with significant reduces in circulating B- and T-cells, particularly in central and naïve memory T-cells, with lesser reductions on effector memory T-cells [15]. As a result of its lipophilic nature, it crosses the blood-brain barrier (BBB) and possibly also down modulates S1P1 in astrocytes and neural cells, thereby decreasing astrogliosis, a phenomenon associated with neurodegeneration in MS [16].

A recent multicenter, randomized, double-blind, placebo-controlled Phase III study with extension in RRMS Pt demonstrated that compared with placebo, it orally at doses of 1.25 and $5 \mathrm{mg}$, decreased the relapse rates by $50 \%$ and number of new focal inflammatory lesions by $80 \%$ [9]. About two years, the average annualized relapse rate in Pt receiving it was $0.21,80 \%$ remained free of new enhancing MRI lesions and $75 \%-77 \%$ of Pt remained free of relapses. In addition, Pt initially receiving placebo showed a significant improvement in clinical parameters of MS after switching to it in the extension study, which was sustained at month 24 [44]. Side effects included nausea, headaches, nasopharyngitis, bradycardia, diarrhea, and dyspnea. In the $5 \mathrm{mg}$ dose group bradycardia was seen more frequently. One case of melanoma, three of basal cell carcinoma and three of squamous cell carcinoma were reported. Two fatalities occurred during the trial, and were associated with herpes and chicken pox virus infection. In addition, a single case of hemorrhagic encephalitis was reported but with an unclear causal relationship [17].

\subsection{SB-683699}

It is an oral medication that is thought to inhibit leukocyte trafficking across the BBB by antagonism of alpha-4 integrins. A Phase II trial in Pt with RRMS evaluating the efficacy and safety of it (150 - $1200 \mathrm{mg}$ twice daily) in the development of MRI-confirmed new brain lesions at six months [18].

\section{Non-Specific Immune Modulation}

\subsection{Laquinimod (Quinoline-3-Carboxamid)}

It is a once-daily, orally administered immunomodulatory compound that is being developed as a disease- modifying therapy for RRMS. The anti-inflammatory properties of it are thought to be secondary to down regulation of major histocompatibility complex Class II gene transcription factors, stimulation of neurotrophin-4, neurotrophin-3 and, suppression of the metabolic activity of CD14+ and NK cells, promotion of apoptosis in CD8+ and B-cells, activation of the anti-inflammatory IL-4 pathway in CD4+ cells, and brain-derived neurotrophic factor. As a result, there is a cytokine balance in favor of anti-inflammatory T-helper (Th)-2/Th-3 cytokines, with inhibition of proinflammatory and cytokine-related genes. A Phase IIb study in $306 \mathrm{Pt}$ demonstrated that an oral daily $0.6 \mathrm{mg}$ dose of it significantly decreased MRI disease activity by a median of $60 \%$ versus placebo in 
RRMS Pt [19]. A Phase III trial was evaluating the efficacy of it $0.6 \mathrm{mg}$ daily in Pt with RRMS [20].

It appears to be well tolerated, with only transient and dose-dependent raises in liver enzymes. A case of Budd-Chiari syndrome occurred after one month of exposure in a patient with underlying hypercoagulability. Unlike its precursor substance, linomide, no cases of serositis or myocardial infarction have been reported so far in Pt receiving it [44].

\subsection{BG00012}

It is an oral formulation of dimethyl fumarate (DF) that may exert a combination of anti-inflammatory and neuroprotective biological effects. Although its exact mechanism of action is not known, it is thought to inhibit immune cells by stimulating the expression of anti-inflammatory cytokines, such as IL-10, IL-4, and IL-5. Hence, it is thought that DF can cause a shift from a Th-1 (pro-inflammatory) to a Th-2 (anti-inflammatory) T-cell response [21]. By producing Phase II detoxification genes and upregulation of the Phase II detoxification enzyme, $\mathrm{NAD}(\mathrm{P}) \mathrm{H}$ :quinone oxidoreductase-1, it may have a neuroprotective therapeutic effect [22].

A previous multicenter, controlled clinical trial of it orally involving 257 people with RRMS receiving various doses of BG00012 capsules or placebo showed a dose-dependent reduction in active inflammation on MRI scans [23]. Tolerability was good overall, with side effects, including flushing and abdominal pain, commonly occurring in the active treatment group [44].

\subsection{Teriflunomide}

It is an inhibitor of mitochondrial dihydroorotate dehydrogenase, an enzyme critically involved in pyrimidine synthesis (PS). Because activated lymphocytes largely depend on de novo PS, decrease of pyrimidine might result in inhibition of immune-cell proliferation [24]. There is some evidence from in vitro studies suggesting that it causes Th-2-mediated anti-inflammatory cytokine activation.

Orally it was tested in a randomized, double-blind, placebo-controlled Phase II study. Pt with relapsing forms of MS was randomized to receive placebo, its 7 or $14 \mathrm{mg}$ a day for 36 weeks. It demonstrated a dose-dependent reduction in the number of $\mathrm{T}_{1}$-enhancing lesions. It was generally safe and well tolerated. Side effects included arthralgia, diarrhea, alopecia, limb pain, nausea, and nasopharyngitis. Pancytopenia and Hepatic necrosis have been reported in Pt with RA taking it.

A two-year, double-blind, placebo-controlled Phase III study in relapsing MS is in progress [25]. The primary outcome measure is relapse rate. Other ongoing or planned studies of it include a Phase II study of combination with glatiramer acetate, a Phase II study of combination with IFN- $\beta$ and a placebo-controlled Phase III trial in clinically isolated syndrome [26]-[28].

\section{Failed Trials}

\subsection{Antigen-Based Immune Therapies}

By antigen-based immune therapy, producing of tolerance appears to be a promising strategy in the treatment of autoimmune disorders. Evaluating the induction of a myelin basic protein-derived peptide (MBP8298) in Pt with progressive forms of MS suggested a benefit in disease progression by clinical parameters in a subgroup of $\mathrm{Pt}$ with HLA-DR4 and DR2 haplotypes in recent studies [44]. Unfortunately two Phase III/II trials investigating MBP9298 in RRMS and SPMS Pt with HLA-DR2 and four haplotypes were negative [29] [30].

\subsection{IL-12 and IL-23 Inhibitors}

Both have been strongly implicated in the pathogenesis of MS. IL-23 is induced by activated myeloid cells, and stabilizes and promotes IL-17 production by CD4+ T-cells, with subsequent tissue inflammation. Circulating mononuclear cells from Pt with MS express high concentrations of IL-23 and IL-12. Ustekinumab is a fully human monoclonal Ab against IL-23/12 p40 that neutralizes IL-23 and IL-12. A Phase II, multicentre, randomised, double-blind, placebo-controlled study was performed evaluating the induction of 27,90 , or $180 \mathrm{mg}$ ustekinumab every four weeks or $90 \mathrm{mg}$ ustekinumab every eight weeks versus placebo. This study did not explain a significant benefit on formation of inflammatory white matter lesions or affect clinical events in Pt with RRMS unfortunately [31]. 


\subsection{Atacicept}

It is an immunoglobulin (Ig) fusion protein tumor necrosis factor family receptor transmembrane activator, calcium modulator, and cyclophilin ligand interactor which sequesters the B-lymphocyte stimulator of the tumor necrosis factor family (BLys), a proliferation-inducing ligand (APRIL), and B-cell survival factor and thus stops later stages of B-cell development [44]. A recent Phase II clinical trial evaluating safety and efficacy profiles in Pt with MS was stopped because preliminary data suggested an increase in disease activity in Pt receiving it [32].

\section{Remyelination and Neural Repair}

CNS remyelination is mostly taken place by oligodendrocyte (OD) progenitor cells. The remyelination ability is in general incomplete and fails over time. Many environmental factors play a crucial role in promoting or inhibiting myelin repair and OD differentiation. Of these, neurite outgrowth inhibitor Nogo-A and its co-receptors, LINGO-1 and TROY have been studied in both in vivo and in vitro studies [33]. Injection of anti-Nogo-A Ab resulted in significant axonal growth in vitro and in animal models of spinal cord injury [34]. Passive immunization with anti-Nogo-A Ab in animal models of MS resulted in less axonal damage and demyelination compared with controls [35]. Over-expression of LINGO-1 stopped OD myelination and differentiation, whereas attenuation of its function or administration of LINGO-1 antagonist Ab (anti-LINGO-1) increased OD myelination and differentiation [36] [37]. In vivo studies explain the presence of LINGO-1 and TROY in a subpopulation of reactive astrocytes, microglia and macrophages in MS brain lesions [38]. Therapy with an Ab antagonist to LINGO-1 function causes the functional recovery and enhanced integrity of axons in rats with experimental autoimmune encephalomyelitis produced by myelin-OD-glycoprotein [39]. Studies of an anti-LINGO-1 monoclonal antibody are under consideration.

Cellular remyelinating strategies, involving both neural stem and embryonic cells, are being proposed as an elective source of brain cells for transplantation and treatment for MS. In vitro studies explain that through trans-differentiation neuronal stem cells have the potential to restore neuronal activity and produce new neurons [44]. Adult bone marrow-derived stromal cells were shown to induce similar neuro-regenerative and immunomodulatory effects in the animal model of chronic experimental autoimmune encephalomyelitis [40] [41]. These concepts have led to an interest in the use of stem cells for restoration of neurologic function and neuronal regeneration in MS. Explaining the use of autologous stem cells for the treatment of MS in humans, there are two clinical trials [42] [43].

\section{Conflict of Interests}

Muhammad Nadeem reports no conflicts of interest in this work and reports no financial relationships/grant support from any NGO or Company.

\section{References}

[1] Seto, S., Carrera, C.J., Kubota, M., Wasson, D.B. and Carson, D.A. (1985) Mechanism of Deoxyadenosine and 2-Chlorodeoxyadenosine Toxicity to Nondividing Human Lymphocytes. Journal of Clinical Investigation, 75, $37-83$. http://dx.doi.org/10.1172/JCI111710

[2] Spurgeon, S., Yu, M., Phillips, J.D. and Epner, E.M. (2009) Cladribine: Not Just Another Purine Analogue? Expert Opinion on Investigational Drugs, 18, 1169-1181. http://dx.doi.org/10.1517/13543780903071038

[3] Beutler, E., Sipe, J.C., Romine, J.S., Koziol, J.A., McMillan, R. and Zyroff, J. (1996) The Treatment of Chronic Progressive Multiple Sclerosis with Cladribine. Proceedings of the National Academy of Sciences of the United States of America, 93, 1716-1720. http://dx.doi.org/10.1073/pnas.93.4.1716

[4] Rice, G.P., Filippi, M. and Comi, G. (2000) Cladribine and Progressive MS: Clinical and MRI Outcomes of a Multicenter Controlled Trial. Cladribine MRI Study Group. Neurology, 54, 1145-1155. http://dx.doi.org/10.1212/WNL.54.5.1145

[5] Romine, J.S., Sipe, J.C., Koziol, J.A., Zyroff, J. and Beutler, E. (1999) A Double-Blind, Placebo-Controlled, Randomized Trial of Cladribine in Relapsing-Remitting Multiple Sclerosis. Proceedings of the Association of American Physicians, 111, 35-44. http://dx.doi.org/10.1046/j.1525-1381.1999.09115.X

[6] Serono, E. (2014) CLARITY: A Phase III, Randomized, Double-Blind, Three-Arm, Placebo-Controlled, Multi-Center Study to Evaluate the Safety and Efficacy of Oral Cladribine in Subjects with Relapsing-Remitting Multiple Sclerosis. 
NCT00213135.

[7] Coles, A.J., Compston, D.A., Selmaj, K.W., et al. (2008) Alemtuzumab vs Interferon Beta-1a in Early Multiple Sclerosis. The New England Journal of Medicine, 359, 1786-1801. http://dx.doi.org/10.1056/NEJMoa0802670

[8] Hauser, S.L., Waubant, E., Arnold, D.L., et al. (2008) B-Cell Depletion with Rituximab in Relapsing-Remitting Multiple Sclerosis. The New England Journal of Medicine, 358, 676-688. http://dx.doi.org/10.1056/NEJMoa0706383

[9] Hawker, K., O’Connor, P., Freedman, M.S., et al. (2009) Rituximab in Patients with Primary Progressive Multiple Sclerosis: Results of a Randomized Double-Blind Placebo-Controlled Multicenter Trial. Annals of Neurology, 66, 460471. http://dx.doi.org/10.1002/ana.21867

[10] Genentech, H.L.R. (2011) Phase II, Multicenter, Randomized, Parallel-Group, Partially Blinded, Placebo and Avonex Controlled Dose Finding Study to Evaluate the Efficacy as Measured by Brain MRI Lesions, and Safety of 2 Dose Regimens of Ocrelizumab in Patients with RRMS. NCT00676715.

[11] Bielekova, B., Catalfamo, M., Reichert-Scrivner, S., et al. (2006) Regulatory CD56 (Bright) Natural Killer Cells Mediate Immunomodulatory Effects of IL-2R Alpha-Targeted Therapy (Daclizumab) in Multiple Sclerosis. Proceedings of the National Academy of Sciences of the United States of America, 103, 5941-5946. http://dx.doi.org/10.1073/pnas.0601335103

[12] Bielekova, B., Richert, N., Howard, T., et al. (2004) Humanized Anti-CD25 (Daclizumab) Inhibits Disease Activity in Multiple Sclerosis Patients Failing to Respond to Interferon Beta. Proceedings of the National Academy of Sciences of the United States of America, 101, 8705-8708. http://dx.doi.org/10.1073/pnas.0402653101

[13] Bielekova, B., Howard, T., Packer, A.N., et al. (2009) Effect of Anti-CD25 Antibody Daclizumab in the Inhibition of Inflammation and Stabilization of Disease Progression in Multiple Sclerosis. Archives of Neurology, 66, 483-489. http://dx.doi.org/10.1001/archneurol.2009.50

[14] Viglietta, V., Bourcier, K., Buckle, G.J., et al. (2008) CTLA4Ig Treatment in Patients with Multiple Sclerosis: An Open-Label, Phase 1 Clinical Trial. Neurology, 71, 917-924. http://dx.doi.org/10.1212/01.wnl.0000325915.00112.61

[15] Mehling, M., Brinkmann, V., Antel, J., et al. (2008) FTY720 Therapy Exerts Differential Effects on T Cell Subsets in Multiple Sclerosis. Neurology, 71, 1261-1267. http://dx.doi.org/10.1212/01.wnl.0000327609.57688.ea

[16] Brinkmann, V. (2009) FTY720 (Fingolimod) in Multiple Sclerosis: Therapeutic Effects in the Immune and the Central Nervous System. British Journal of Pharmacology, 158, 1173-1182. http://dx.doi.org/10.1111/j.1476-5381.2009.00451.x

[17] Novartis (2014) TRANSFORMS FTY720. A 12-Month Study Comparing the Efficacy and Safety of Two Doses of Fingolimod versus Interferon $\beta$-1a in Patients with Relapsing-Remitting Multiple Sclerosis with Optional Extension Phase. NCT00340834.

[18] GlaxoSmithKline (2012) Randomised, Double-Blind, Placebo-Controlled, Parallel-Group, Dose-Ranging Study to Investigate the MRI Efficacy and the Safety of Six Months' Administration of SB-683699 in Subjects with Relapsing-Remitting Multiple Sclerosis. NCT00395317.

[19] Comi, G., Pulizzi, A., Rovaris, M., et al. (2008) Effect of Laquinimod on MRI-Monitored Disease Activity in Patients with Relapsing-Remitting Multiple Sclerosis: A Multicentre, Randomised, Double-Blind, Placebo-Controlled Phase IIb Study. The Lancet, 371, 2085-2092. http://dx.doi.org/10.1016/S0140-6736(08)60918-6

[20] Teva Pharmaceutical Industries (2016) A Multinational, Multicenter, Open-Label, Single-Assignment Extension of the MS-LAQ-301 Study, to Evaluate the Long-Term Safety, Tolerability and Effect on Disease Course of Daily Oral Laquinimod 0.6 mg in Subjects with Relapsing Multiple Sclerosis. NCT00988052.

[21] De Jong, R., Bezemer, A.C., Zomerdijk, T.P., van de Pouw-Kraan, T., Ottenhoff, T.H. and Nibbering, P.H. (1996) Selective Stimulation of T Helper 2 Cytokine Responses by the Anti-Psoriasis Agent Monomethyl Fumarate. European Journal of Immunology, 26, 2067-2074. http://dx.doi.org/10.1002/eji.1830260916

[22] Wierinckx, A., Breve, J., Mercier, D., Schultzberg, M., Drukarch, B. and Van Dam, A.M. (2005) Detoxication Enzyme Inducers Modify Cytokine Production in Rat Mixed Glial Cells. Journal of Neuroimmunology, 166, 132-143. http://dx.doi.org/10.1016/j.jneuroim.2005.05.013

[23] Schimrigk, S., Brune, N., Hellwig, K., et al. (2006) Oral Fumaric Acid Esters for the Treatment of Active Multiple Sclerosis: An Open-Label, Baseline-Controlled Pilot Study. European Journal of Neurology, 13, 604-610. http://dx.doi.org/10.1111/j.1468-1331.2006.01292.x

[24] Korn, T., Magnus, T., Toyka, K. and Jung, S. (2004) Modulation of Effector Cell Functions in Experimental Autoimmune Encephalomyelitis by Leflunomide-Mechanisms Independent of Pyrimidine Depletion. Journal of Leukocyte Biology, 76, 950-960. http://dx.doi.org/10.1189/jlb.0504308

[25] Sanofi-Aventis (2016) Long-Term Extension of the Multinational, Double-Blind, Placebo Controlled Study EFC6049 (HMR1726D/3001) to Document the Safety of Two Doses of Teriflunomide (7 and $14 \mathrm{mg}$ ) in Patients with Multiple Sclerosis with Relapses. NCT00803049. 
[26] Sanofi-Aventis (2012) A Randomized, Multinational, Double-Blind, Placebo-Controlled, Parallel-Group Design Pilot Study to Estimate the Tolerability, Safety, Pharmacokinetics, and Pharmacodynamic Effects of Teriflunomide for 24 Weeks when Added to Treatment with Glatiramer Acetate in Subjects with Multiple Sclerosis. NCT00475865.

[27] Sanofi-Aventis (2012) A Randomized, Multinational, Double-Blind, Placebo-Controlled, Parallel-Group Design Pilot Study to Estimate the Tolerability, Safety, Pharmacokinetics, and Pharmacodynamic Effects of Teriflunomide for 24 Weeks when Added to Treatment with Interferon-Beta in Subjects with Multiple Sclerosis. NCT00489489.

[28] Sanofi-Aventis (2016) An International, Multi-Center, Randomized, Double-Blind, Placebo-Controlled, Parallel Group Study to Evaluate the Efficacy and Safety of Two Year Treatment with Teriflunomide $7 \mathrm{mg}$ Once Daily and $14 \mathrm{mg}$ Once Daily versus Placebo in Patients with a First Clinical Episode Suggestive of Multiple Sclerosis. NCT00622700.

[29] Eli Lilly and Company (2010) An Open Label Follow-On Study to Assess the Ongoing Safety of MBP8298 in Subjects with Secondary Progressive Multiple Sclerosis. NCT00870155.

[30] Eli Lilly and Company (2010) A Double-Blind, Placebo Controlled Multicentre Study to Evaluate the Efficacy and Safety of MBP8298 in Subjects with Secondary Progressive Multiple Sclerosis. NCT00869726.

[31] Centocor, I. (2012) A Phase II, Double-Blind, Placebo-Controlled, Randomized, Dose-Ranging Study of Multiple Subcutaneous Injections of Human Monoclonal Antibody to IL-12 p40 (CNTO1275) in Subjects with Relapsing-Remitting Multiple Sclerosis. NCT00207727.

[32] EMD Serono (2016) An Open-Label, Multicenter Phase II Extension of Study 28063 (ATAMS) to Obtain Long-Term Follow-Up Data in Subjects with Relapsing Multiple Sclerosis Treated with Atacicept for up to 5 Years (ATAMS-Extension). NCT00853762.

[33] Karnezis, T., Mandemakers, W., McQualter, J.L., et al. (2004) The Neurite Outgrowth Inhibitor Nogo A Is Involved in Autoimmune-Mediated Demyelination. Nature Neuroscience, 7, 736-744. http://dx.doi.org/10.1038/nn1261

[34] Liebscher, T., Schnell, L., Schnell, D., et al. (2005) Nogo-A Antibody Improves Regeneration and Locomotion of Spinal Cord-Injured Rats. Annals of Neurology, 58, 706-719. http://dx.doi.org/10.1002/ana.20627

[35] Fontoura, P., Ho, P.P., DeVoss, J., et al. (2004) Immunity to the Extracellular Domain of Nogo-A Modulates Experimental Autoimmune Encephalomyelitis. The Journal of Immunology, 173, 6981-6992. http://dx.doi.org/10.4049/jimmunol.173.11.6981

[36] Mi, S., Miller, R.H., Lee, X., et al. (2005) LINGO-1 Negatively Regulates Myelination by Oligodendrocytes. Nature Neuroscience, 8, 745-751. http://dx.doi.org/10.1038/nn1460

[37] Lee, X., Yang, Z., Shao, Z., et al. (2007) NGF Regulates the Expression of Axonal LINGO-1 to Inhibit Oligodendrocyte Differentiation and Myelination. The Journal of Neuroscience, 27, 220-225. http://dx.doi.org/10.1523/JNEUROSCI.4175-06.2007

[38] Satoh, J., Tabunoki, H., Yamamura, T., Arima, K. and Konno, H. (2007) TROY and LINGO-1 Expression in Astrocytes and Macrophages/Microglia in Multiple Sclerosis Lesions. Neuropathology and Applied Neurobiology, 33, 99107. http://dx.doi.org/10.1111/j.1365-2990.2006.00787.x

[39] Mi, S., Miller, R.H., Tang, W., et al. (2009) Promotion of Central Nervous System Remyelination by Induced Differentiation of Oligodendrocyte Precursor Cells. Annals of Neurology, 65, 304-315. http://dx.doi.org/10.1002/ana.21581

[40] Rafei, M., Campeau, P.M., Aguilar-Mahecha, A., et al. (2009) Mesenchymal Stromal Cells Ameliorate Experimental Autoimmune Encephalomyelitis by Inhibiting CD4 Th17 T Cells in a CC Chemokine Ligand 2-Dependent Manner. The Journal of Immunology, 182, 5994-6002. http://dx.doi.org/10.4049/jimmunol.0803962

[41] Pluchino, S., Quattrini, A., Brambilla, E., et al. (2003) Injection of Adult Neurospheres Induces Recovery in a Chronic Model of Multiple Sclerosis. Nature, 422, 688-694. http://dx.doi.org/10.1038/nature01552

[42] Hadassah Medical Organization (2016) Explorative Trial to Investigate the Migration Ability of Mesenchymal Bone Marrow Stem Cells (MSC) in the Central Nervous System (CNS) Following Their Intrathecal Administration in Severe Cases of Multiple Sclerosis (MS). 1872 NCT0078.

[43] The Cleveland Clinic and University Hospital Case Medical Center (2016) A Phase I Study to Assess the Feasibility, Safety, and Tolerability of Autologous Mesenchymal Stem Cell Transplantation in Patients with Relapsing Forms of Multiple Sclerosis. NCT00813969.

[44] Corboy, J.R. and Miravalle, A.A. (2010) Emerging Therapies for Treatment of Multiple Sclerosis. Journal of Inflammation Research, 3, 53-59. http://dx.doi.org/10.2147/JIR.S6558

[45] Weinstock-Guttman, B., Hagemeier, J., Kavak, K.S., Saini, V., Patrick, K., Ramasamy, D.P., Nadeem, M., Carl, E., Hojnacki, D. and Zivadinov R. (2016) Randomised Natalizumab Discontinuation Study: Taper Protocol May Prevent Disease Reactivation. Journal of Neurology, Neurosurgery \& Psychiatry, 1-7. 


\section{Abbreviations}

HZV, herpes zoster virus; RR, relapse rate; HA, headaches; SAD, sustained acumulation of disability; IV, intravenous; ITP, immune thrombocytopenic purpura; CEL, contrast enhancing MRI lesions; SQ, subcutaneous; LFT, liver function test; RRMS, relapsing remitting Multiple Sclerosis.

\section{Submit or recommend next manuscript to SCIRP and we will provide best service for you:}

Accepting pre-submission inquiries through Email, Facebook, Linkedin, Twitter, etc A wide selection of journals (inclusive of 9 subjects, more than 200 journals)

Providing a 24-hour high-quality service

User-friendly online submission system

Fair and swift peer-review system

Efficient typesetting and proofreading procedure

Display of the result of downloads and visits, as well as the number of cited articles

Maximum dissemination of your research work

Submit your manuscript at: http://papersubmission.scirp.org/ 